\title{
Serological prevalence of Toxoplasma gondii infection in cats (Belém, Pará, Brazil)
}

\author{
Prevalência sorológica de infecção por Toxoplasma gondii em gatos \\ (Belém, Pará, Brasil) \\ Katarine de Souza Rocha; Michele de Souza Lima²; Thamillys Rayssa Marques Monteiro3; \\ Betsy Emely Tavares Honorio'; Ana Paula Vilhena Beckman Pinho4; Giselle Souza da Paz; ${ }^{5}$ Alessandra Scofield6; \\ Gustavo Góes Cavalcante ${ }^{6}$; Paulo Cesar Magalhães-Matos; ; Francisco Dantas Sampaio Junior ${ }^{6}$; Isis Abel; \\ Helio Langoni5; Carla Cristina Guimarães de Moraes ${ }^{1 *}$ (1)
${ }^{1}$ Laboratório de Zoonoses e Saúde Pública, Faculdade de Medicina Veterinária, Instituto de Medicina Veterinária, Universidade Federal do Pará - UFPA, Castanhal, PA, Brasil
${ }^{2}$ Médica Veterinária Autônoma, Belém, PA, Brasil
${ }^{3}$ Laboratório de Biologia Molecular, Instituto de Saúde e Produção Animal - ISPA, Universidade Federal Rural da Amazônia - UFRA, Belém, PA, Brasil
${ }^{4}$ Agência de Defesa Agropecuária do Pará - ADEPARÁ, Belém, PA, Brasil
${ }^{5}$ Departamento de Higiene Veterinária e Saúde Pública, Faculdade de Medicina Veterinária e Zootecnia, Universidade Estadual Paulista "Júlio de Mesquita Filho" - UNESP, Botucatu, SP, Brasil
${ }^{6}$ Laboratório de Parasitologia Veterinária, Faculdade de Medicina Veterinária, Instituto de Medicina Veterinária, Universidade Federal do Pará - UFPA, Castanhal, PA, Brasil
${ }^{7}$ Curso de Medicina Veterinária, Centro de Ciências Biológicas e da Saúde, Universidade da Amazônia - UNAMA, Belém, PA, Brasil
${ }^{8}$ Laboratório de Epidemiologia e Geoprocessamento, Faculdade de Medicina Veterinária, Instituto de Medicina Veterinária, Universidade Federal do Pará - UFPA, Castanhal, PA, Brasil

How to cite: Rocha KS, Lima MS, Monteiro TRM, Honorio BET, Pinho APVB, Paz GS, et al. Serological prevalence of Toxoplasma gondii infection in cats (Belém, Pará, Brazil). Braz J Vet Parasito/ 2020; 29(2): e022719. https://doi.org/10.1590/S1984-29612020038

\begin{abstract}
We evaluated the prevalence of anti-Toxoplasma gondii antibodies in the serum samples collected from domestic cats in Belém, Pará, Brazil. We also correlated the presence of $T$. gondii antibodies with environmental variables and cat-owner habits. Four-hundred and forty-seven serum samples from domestic cats were analyzed. The sera were tested using an indirect immunofluorescence assay. Among the animals analyzed, 21.92\% (98/447) were seropositive. A statistically significant association was found in relation to age and serology among the animals over 1 year old $(p<0.01)$ : in the group up to 1 year old, $12.82 \%$ (20/156) of the animals were positive, and in the group over 1 year old, 26.80\% (78/291) were positive. Our results show that the cats in Belém, Pará region have anti-T. gondii antibodies, and their owners are not aware of toxoplasmosis or how to prevent its transmission.
\end{abstract}

Keywords: Toxoplasmosis, feline, IFA.

\section{Resumo}

Foi avaliada a prevalência de anticorpos anti-Toxoplasma gondii em amostras de soro, coletadas de gatos domésticos, em Belém, Pará, Brasil. Também correlacionou-se a presença de anticorpos contra T. gondii com variáveis ambientais e hábitos de proprietários. Quatrocentas e quarenta e sete amostras de soro de gatos domésticos foram analisadas. Os soros foram testados por ensaio de imunofluorescência indireta, e as amostras de fezes foram analisadas por meio de reação em cadeia da polimerase. Entre os animais analisados, 21,92\% (98/447) foram soropositivos. Foi encontrada associação estatística significante em relação à idade e à sorologia entre os animais acima de 1 ano $(p<0,01)$ : no grupo de até 1 ano, 12,82\% (20/156) dos animais positivos e, no grupo acima de 1 ano, 26,80\% (78/291) positivos. Os resultados mostram que os gatos daquela região possuem anticorpos anti-T. gondii, e seus donos não estão cientes da toxoplasmose ou de como evitar sua transmissão.

Palavras-chave: Toxoplasmose, felinos, IFA. 


\section{Introduction}

Toxoplasma gondii (phylum Apicomplexa, family Sarcocystidae) is an obligate intracellular enteric coccidian parasite that infects domestic cats and other felids (Bowman, 2010; Frenkel \& Bermudez, 2006). This agent has a wide geographic distribution and infects several warm-blooded animals, including aquatic mammals and humans. Therefore, the disease caused by this pathogen, toxoplasmosis, is an anthropozoonosis (Kawazoe, 2005). Cats are the definitive hosts of $T$. gondii, while the other susceptible species are intermediate hosts. Infection usually occurs by ingesting tissue cysts or pseudocysts present in different animal tissues or by ingesting food or water contaminated with sporulated oocysts (Dabritz et al., 2007; Elmore et al., 2010).

In Belém, the state capital of Pará (Brazil), the household cat population was estimated at 48,838, per the Center for Zoonosis Control of Belém (personal contact, 2010). The state capital, despite having a high rate of congenital toxoplasmosis in humans, which is characterized by primary infection in pregnant women that is consequently transferred to the fetus through the placenta in the first trimester of pregnancy and can lead to serious problems such as abortion, fetal death, premature births, or late side effects such as visual problems (Bichara et al., 2012), does not have a program for controlling population of stray cats, and there is no government incentive to raise awareness of responsible pet ownership.

Several studies have provided data on the seroprevalence of $T$. gondii in cats domiciled in different regions of the country (Lucas et al., 1999; Langoni et al., 2001; Netto et al., 2003; Cavalcante et al., 2006; Dalla Rosa et al., 2010), however, data on cats in Belém are lacking. Therefore, the present study aimed to evaluate the prevalence of anti-T. gondii IgG antibodies in the sera of domestic cats in Belém. We also examined the possible risk factors and cat-owner's knowledge of toxoplasmosis.

\section{Materials and Methods}

\section{Sampling and collection location}

Biological samples were collected from one cat per household in Belém, Pará $\left(01^{\circ} 27^{\prime} 21^{\prime \prime} \mathrm{S}, 48^{\circ} 30^{\prime} 16^{\prime \prime} \mathrm{W}\right)$ totaling 447 blood samples, regardless of gender, age, or breed. From the estimate of the number of cats living in the city provided by the Zoonosis Control Center on the basis of the vaccine dose given to dogs and cats during the 2009 rabies vaccination campaign, sample size calculation was performed, with a expect frequency prevalence of 50\% and $95 \%$ confidence interval using the simple random sample formula proposed by Thrusfield (2007).

Blood collection was performed aseptically by venipuncture of the cephalic or jugular vein. Approximately $2-5 \mathrm{~mL}$ of blood was collected using $5 \mathrm{~mL}$ syringes and tubes without anticoagulants. The samples were transported to the Zoonoses and Public Health Laboratory of the Institute of Veterinary Medicine of the Federal University of Pará (IMV/UFPA), where they were centrifuged at $1200 \mathrm{rpm}$ for 15 minutes to separate coagulated blood from serum. The serum was placed in $1.5 \mathrm{~mL}$ Eppendorf ${ }^{\oplus}$ tubes, labeled, and stored at $-20^{\circ} \mathrm{C}$ until analysis.

The animals were divided into two groups according to age. Group 1 consisted of animals less than or equal to 1 year old, and group 2 consisted of cats older than 1 year in age. This study was approved by of the Ethics Committee on Animal Use at the State University of Pará under protocol n 23/2012. In addition, informed consent forms (ICFs) were signed by the animal owners, who also completed epidemiological surveys.

\section{Data analysis}

For analysis of the responses to the questionnaires, a database using the SPSS v.20.0 software $\left({ }^{\circ} 2011\right.$ IBM corporation, United States) was created. The verification of associations between variables was conducted using the chi-square test. When associations were present, the odds ratio was calculated. The $95 \% \mathrm{Cl}$ was used to determine the significance of differences.

\section{Sample analysis}

Analysis of the anti-T. gondii antibody was performed by detecting specific IgG using an indirect immunofluorescence assay (IFA), using a 1:16 dilution as the cut-off (Camargo, 1974). The sera were diluted up to 1:1024 in phosphate-buffered saline and placed on glass slides coated with the $T$. gondii tachyzoites antigen (RH strain). Then, we used fluorescein-conjugated anti-cat IgG (SAB700065-2MG anti-cat IgG FC specific + fluorescein isothiocyanate ( ${ }^{\circ} \mathrm{SIGMA}$-Aldrich, San Luis, Missouri, EUA). As positive control, we used a positive cat serum sample for $T$. gondii treated at the veterinary hospital at UNESP-Botucatu. Samples were considered positive when at least $50 \%$ of the tachyzoites per field exhibited fluorescence. The positivity titer was related to the last dilution that still showed fluorescence. 


\section{Results}

Among the 447 samples analyzed using IFA, 21.92\% (98/447) of the animals were found to be seropositive. The values for the antibody titers ranged from 16 to 1024. Most of the animals, 39.80\% (39/98), had a titer of 64, and the fewest proportion of animals, 6.12\% (6/98), had a titer of 1024. The variables, gender, race, diet, and behavioral habits, were not found to be associated with serological results. With respect to age, being over 1 year old was found to be a risk factor for $T$. gondii seropositivity; $12.82 \%$ (20/156) of the animals in group 1 were positive, with animals in that group 2.49 (odds) chances of presenting positive results, while $26.80 \%$ (78/291) in group 2 were positive, indicating an association between age and serological findings (Table 1). It was observed that 74\% (331/447) and 93.50\% (418/447) of cat breeders were unaware of the disease and its modes of transmission, respectively (Table 2).

Table 1. Factors associated with the seroprevalence of Toxoplasma gondii in domestic cats (Belém, Pará, Brazil).

\begin{tabular}{|c|c|c|c|c|c|c|c|c|}
\hline \multirow{3}{*}{ Variable } & \multicolumn{4}{|c|}{ RIFI and Univariate analysis } & \multicolumn{4}{|c|}{ Logistic regression } \\
\hline & \multicolumn{2}{|c|}{ Positive $(n=98)$} & \multicolumn{2}{|c|}{ Negative $(n=349)$} & \multirow{2}{*}{ P-value } & \multirow{2}{*}{$O R^{(3)}$} & \multirow{2}{*}{ P-value ${ }^{(4)}$} & \multirow{2}{*}{$95 \% \mathrm{Cl}^{(5)}$} \\
\hline & $n$ & $\%$ & $\mathrm{n}$ & $\%$ & & & & \\
\hline Sex & & & & & 0.57 & 1.140 & 0.57 & $0.717-1.812$ \\
\hline Male $^{(1)}$ & 36 & 36.73 & 139 & 39.82 & & & & \\
\hline Female & 62 & 63.26 & 210 & 60.17 & & & & \\
\hline Breed & & & & & 0.217 & 0.761 & 0.274 & $0.467-1.242$ \\
\hline Breed $^{(1)}$ & 27 & 27.55 & 73 & 21.19 & & & & \\
\hline Mixed-breed & 71 & 72.44 & 275 & 78.79 & & & & \\
\hline Age & & & & & 0.01 & 2.490 & 0.001 & $0.264-0.725$ \\
\hline Up to $1 \mathrm{yr}$. old ${ }^{(1)}$ & 20 & 20.41 & 136 & 38.97 & & & & \\
\hline$>1 \mathrm{yr}$. old & 78 & 79.59 & 213 & 61.03 & & & & \\
\hline Outdoor access & & & & & 0.56 & 1.489 & 0.318 & $0.678-3.310$ \\
\hline$Y_{e s}^{(1)}$ & 85 & 86.73 & 310 & 88.82 & & & & \\
\hline No & 13 & 13.26 & 39 & 11.17 & & & & \\
\hline Eating raw meat & & & & & 0.092 & 0.947 & 0.274 & $0.863-1.038$ \\
\hline $\operatorname{Yes}^{(1)}$ & 41 & 41.83 & 114 & 32.66 & & & & \\
\hline No & 57 & 58.16 & 235 & 67.33 & & & & \\
\hline Hunting & & & & & 0.63 & 1.153 & 0.634 & $0.642-2.072$ \\
\hline$Y_{e s}^{(1)}$ & 81 & 82.65 & 281 & 80.51 & & & & \\
\hline No & 17 & 17.35 & 68 & 19.48 & & & & \\
\hline
\end{tabular}

n: number; (1)Reference categories; (2)P-value (Chi-square test); ${ }^{(3)}$ Odds ratio; ${ }^{(4)}$ P-value (Logistic regression); ${ }^{(5)} \mathrm{Cl}$ : confidence interval.

Table 2. Association between owner awareness and seroprevalence of Toxoplasma gondii in domestic cats (Belém, Pará, Brazil).

\begin{tabular}{|c|c|c|c|c|c|c|c|c|}
\hline \multirow{3}{*}{ Variable } & \multicolumn{5}{|c|}{ RIFI and Univariate analysis } & \multicolumn{3}{|c|}{ Logistic regression } \\
\hline & \multicolumn{2}{|c|}{ Positive $(n=98)$} & \multicolumn{2}{|c|}{ Negative $(n=349)$} & \multirow{2}{*}{ P-value (2) } & \multirow{2}{*}{$\mathrm{OR}^{(3)}$} & \multirow{2}{*}{ P-value (4) } & \multirow{2}{*}{$95 \% \mathrm{Cl}^{(5)}$} \\
\hline & $\mathbf{n}$ & $\%$ & $\mathbf{n}$ & $\%$ & & & & \\
\hline Origin & & & & & 0.21 & 0.723 & 0.195 & $0.443-1.181$ \\
\hline Born at the house $e^{(1)}$ & 68 & 20.48 & 264 & 79.51 & & & & \\
\hline Adopted & 30 & 26.08 & 85 & 73.91 & & & & \\
\hline Disease awareness & & & & & 0.52 & 0.844 & 0.526 & $0.500-1.426$ \\
\hline$Y_{e s}^{(1)}$ & 23 & 19.82 & 93 & 80.17 & & & & \\
\hline No & 75 & 22.65 & 256 & 77.34 & & & & \\
\hline $\begin{array}{l}\text { Awareness of the modes of } \\
\text { toxoplasmosis transmission }\end{array}$ & & & & & 0.27 & 0.551 & 0.280 & $0.187-1.624$ \\
\hline$Y_{e s}^{(1)}$ & 4 & 13.79 & 25 & 86.20 & & & & \\
\hline No & 94 & 22.48 & 324 & 72.48 & & & & \\
\hline
\end{tabular}

n: number; (1)Reference categories; (2)P-value (Chi-square test); (3)Odds ratio; (4)P-value (Logistic regression); (5)Cl: confidence interval. 


\section{Discussion}

Our results indicate that cats are exposed to $T$. gondii, thus suggesting a high degree of environmental contamination by infective oocysts, similar to the findings of Cavalcante et al. (2006) in Monte Alegre-Rondônia.

In the present study, no statistical association was found between animal sex and serological results ( $p>0.05$ ). This is in line with the results of previous studies showing that men and women are equally at risk of protozoan infection (Dalla Rosa et al., 2010; Pereira et al., 2018).

Hunting and the consumption of raw meat were also not associated with serological results, an observation similar to that reported by Dalla Rosa et al. (2010) and López et al. (2011). Although our study revealed no correction between eating and behavioral habits and the risk of infection in cats, Langoni et al. (2001) and Netto et al. (2003) observed that the prevalence of seropositive animals is directly related to cat behavior. Animals that have unrestricted access to the street are more likely to catch prey, which facilitates infection via the consumption of intermediate parasite hosts (Sroka et al., 2018; Mohammed et al., 2019).

Lucas et al. (1999), who demonstrated that the infection rates in cats that consumed raw meat were significantly different from those of animals that consumed homemade or commercial food ( $p<0.05$ ). However, Mohammed et al. (2019) report that infection via the ingestion of the parasite can affect both free-ranging cats that have a habit of hunting, and those that live indoors and are fed only canned food, provided the food is not cooked properly, similar to the results of the present study.

With respect to age, age greater than 1 year constitutes a risk factor for $T$. gondii seropositivity for animals in group 2 (Table 1), revealing an association between age and the serological findings. It has been suggested that a gradual increase in age is directly related to T. gondii exposure (López et al., 2011; Mohammed et al., 2019).

For a better understanding of our study group, we provided epidemiological findings with questions designed to assess owner awareness, regardless of educational level, regarding toxoplasmosis and modes of transmission to humans. Most were unaware of the disease and its modes of transmission.

These data indicate that the lack of awareness of toxoplasmosis in many owners is probably because the infected cat is asymptomatic. Hence, the agent is eliminated to the environment in imperceptible ways and may contaminate food and water, thereby promoting the transmission of $T$. gondii to humans. Similar assumptions were corroborated by Elmore et al. (2010), Dabritz \& Conrad (2010), and VanWormer et al. (2013). We also observed no significant association between owner awareness and the seroprevalence of their animals $(p>0.05)$.

Although only the age variable correlates with the result of the serological test, research using indirect diagnostic techniques has been shown to be useful in epidemiological studies (Sroka et al., 2018), allowing us to gain insight into the current health status with respect to $T$. gondii infection.

\section{Conclusions}

Many domestic cats in Belém had anti-T. gondii antibodies. Owners also tended to have poor knowledge regarding the modes of transmission of the infectious agent to humans and animals.

\section{Acknowledgements}

We appreciate the support of the Dean of Research and Graduation Studies and the Foundation for Research Support and Development by edict $n^{\circ}$. 01/2014 Programme for Supporting the Qualified Research and the Coordination of Improvement of Higher Education Personnel for granting the master's scholarship.

\section{References}

Bichara CNC, Canto GAC, Tostes CL, Freitas JJS, Carmo EL, Póvoa MM, et al. Incidence of congenital toxoplasmosis in the city of Belém, State of Pará, Northern Brazil, determined by a neonatal screening program: preliminary results. Rev Soc Bras Med Trop 2012; 45(1): 122-124. http://dx.doi.org/10.1590/S0037-86822012000100024. PMid:22370842.

Bowman DD. Georgis: parasitologia veterinária. Rio de Janeiro: Elsevier; 2010.

Camargo ME. Introdução às técnicas de imunofluorescência. Rev Bras Patol Clin 1974; 10: 87-107. 
Cavalcante GT, Aguiar DM, Chiebao D, Dubey JP, Ruiz VLA, Dias RA, et al. Seroprevalence of Toxoplasma gondii antibodies in cats and pigs from rural Western Amazon, Brazil.J Parasito/ 2006; 92(4): 863-864. http://dx.doi.org/10.1645/GE-830R.1. PMid:16995406.

Dabritz HA, Conrad PA. Cat and Toxoplasma: Implications for Public Health. Zoonoses Public Health 2010; 57(1): 34-52. http:// dx.doi.org/10.1111/j.1863-2378.2009.01273.x. PMid:19744306.

Dabritz HA, Miller MA, Atwill ER, Gardner IA, Leutenegger MC, Melli AC, et al. Detection of Toxoplasma gondii-like oocysts in cat feces and estimates of the environmental oocyst burden. J Am Vet Med Assoc 2007; 231(11): 1676-1684. http://dx.doi.org/10.2460/ javma.231.11.1676. PMid:18052801.

Dalla Rosa L, Moura AB, Trevisani N, Medeiros AP, Sartor AA, Souza AP, et al. Toxoplasma gondii antibodies on domiciled cats from Lages municipality, Santa Catarina State, Brazil. Rev Bras Parasitol Vet 2010; 19(4): 268-269. http://dx.doi.org/10.1590/S198429612010000400017. PMid:21184709.

Elmore SA, Jones JF, Conrad PA, Patton S, Lindsay DS, Dubey JP. Toxoplasma gondii: epidemiology, feline clinical aspects, and prevention. Trends Parasitol 2010; 26(4): 190-196. http://dx.doi.org/10.1016/j.pt.2010.01.009. PMid:20202907.

Frenkel JK, Bermudez JEV. Toxoplasmose. In: Veronesi R, Focaccia R, editors. Tratado de infectologia. São Paulo: Atheneu; 2006. p. 1634-1649.

Kawazoe U. Toxoplasma gondii. In: Neves DP, editor. Parasitologia humana. 11th ed. São Paulo: Atheneu; 2005. p. $163-172$.

Langoni H, Silva AV, Cabral KG, Cunha ELP, Cutolo AA. Prevalência de toxoplasmose em gatos dos Estados de São Paulo e Paraná. Braz J Vet Res Anim Sci 2001; 38(5): 243-244. http://dx.doi.org/10.1590/S1413-95962001000500009.

López C, Daprato B, Zampolini S, Mazzeo C, Cardillo N, Sommerfelt I. Risk factors and prevalence of IgG antibodies to Toxoplasma gondii in domestic cats. La Matanza Buenos Aires, Argentina. Rev Ibero-latinoam Parasitol 2011; 70(1): 29-34.

Lucas SRR, Hagiwara MK, Loureiro VS, Ikesaki JYH, Birgel EH. Toxoplasma gondii infection in brazilian domestic outpatient cats. Rev Inst Med Trop São Paulo 1999; 41(4): 221-224. http://dx.doi.org/10.1590/S0036-46651999000400003. PMid:10564914.

Mohammed OB, Omar OI, Elamin EA, Bushara HO, Omer AS, Alagaili NA. Seroprevalence of Toxoplasma gondii in household and stray cats of Riyadh, Saudi Arabia. Vet Ital 2019; 55(3): 241-245. http://dx.doi.org/10.12834/Vetlt.221.695.4. PMid:31599548.

Netto EG, Munhoz AD, Albuquerque GR, Lopes CWG, Ferreira AMR. Ocorrência de gatos soropositivos para Toxoplasma gondii Nicolle e Manceaux, 1909 (Apicomplexa: Toxoplasmatinae) na cidade de Niterói, Rio de Janeiro. Rev Bras Parasitol Vet 2003; 12(4): 145-149.

Pereira PF, Barbosa AD, Santos ALC, Bolais PF, Dardé ML, Amedoeira MRR. Toxoplasma gondii: infection among shelter and stray cats in Rio de Janeiro, Brazil. Rev Bras Parasito/ Vet 2018; 27(3): 401-408. http://dx.doi.org/10.1590/s1984-296120180061. PMid:30208125.

Sroka J, Karamon J, Dutkiewicz J, Wójcik Fatla A, Zając V, Cencek T. Prevalence of Toxoplasma gondii infection in cats in southwestern Poland. Ann Agric Environ Med 2018; 25(3): 576-580. http://dx.doi.org/10.26444/aaem/94675. PMid:30260170.

Thrusfield M. Veterinary epidemiology. 3rd ed. Oxford: Blackwell Science; 2007.

VanWormer E, Fritz H, Shapiro K, Mazet JAK, Conrad P. Molecules to modeling: toxoplasma gondii oocysts at the human-animalenvironment interface. Comp Immunol Microbiol Infect Dis 2013; 36(3): 217-231. http://dx.doi.org/10.1016/j.cimid.2012.10.006. PMid:23218130. 